\title{
Haberde Söylem Üretimi: 2018 Döviz Kuru Krizinin Haber Medyasındaki Yansımaları
}

\author{
A. Fulya ȘEN ${ }^{1}$ \\ Hacer TAȘDELEN ${ }^{2}$
}

Öz

Türkiye ekonomisi 2018 yılı Temmuz-Ağustos döneminde Türk Lirası'ndaki aşırı değer kaybı nedeniyle zor günler geçirmiş ve döviz kurlarında ani ve keskin yükseliş ve düşüşlerin karakterize ettiği bir kur krizi deneyimlemiştir. Bu çalışmada, haber medyasının neoliberal ideolojiyi doğallaştırmasını örneklemek amacıyla Türkiye ekonomisinde yaşanan kırılganlıklar sonucunda 2018 yılında TL'nin döviz karşısında değer kaybetmesi olarak beliren döviz kuru krizinin haber medyasında nasıl temsil edildiği ve haberin söylemini belirleyen temel öğeler olan sözcük seçimleri ve durum tanımları analiz edilmiştir. Bu çalışma, gazetelerde yer alan haberlerin ardalanındaki ideolojik etkileri ortaya çıkarmak amacıyla, Teun van Dijk'ın haber metinlerine uyguladığı eleştirel söylem çözümlemesi yöntemini kullanarak basının döviz kuru krizi bağlamında ekonomide ortaya çıkan olumsuz tabloyu nasıl tanımladığını incelemiştir.

Anahtar sözcükler: Haber söylemi, İdeoloji, Eleştirel söylem çözümlemesi, Ekonomik kriz

Atıf: Șen, A. F. ve Tașdelen, H. (2019). “Haberde Söylem Üretimi: 2018 Döviz Kuru Krizinin Haber Medyasındaki Yansımaları". Akdeniz Üniversitesi İletișim Fakültesi Dergisi, (AKiL) Haziran (31), s. 254-275

1 Prof. Dr., Fırat Üniversitesi İletişim Fakültesi, fulyasen@firat.edu.tr Orcid ID: 0000-0003-3350-8292 2 Doktorant, Fırat Üniversitesi Sosyal Bilimler Enstitüsü, hacertasdelen@gmail.com Orcid ID: 0000-0002-81220560 


\title{
Discourse Production in News: The Reflections of the Turkish Currency Crisis of 2018 in News Media
}

\begin{abstract}
Turkey's economy has undergone a currency crisis characterized by the sudden and sharp rise and fall of the Turkish Lira in the July-August period of 2018 and it has had a difficult time due to the excessive depreciation of the Turkish Lira and foreign exchange rates. In this study, to illustrate how neoliberal ideology is naturalized by media, it has been examined that how the Turkish Lira crisis which appears in that way of losing value against foreign currency in 2018 is represented by the news media and analysed state definitions and word choices which are the basic elements of the discourse of the news. In order to reveal the ideological impact on news, this study has applied Teun van Dijk's critical discourse analysis method to the news texts and examined how the press define negative situation emerging in the economy in the context of the currency crisis.
\end{abstract}

Keywords: News discourse, Ideology, Critical discourse analysis, Economic crisis

\section{Giriș}

$\mathrm{T}$ ürkiye ekonomisi 2018 yılı Temmuz-Ağustos döneminde Türk Lirası'ndaki aşırı değer kaybı nedeniyle zor günler geçirmiş ve döviz kurlarında ani ve keskin yükseliş ve düşüşlerin karakterize ettiği bir kur krizi deneyimlemiştir. Bu krizi analiz ederken Türkiye ekonomisinin karşı karşıya olduğu kırılganlıkların nedenlerini ve Türkiye'nin büyüme modeli ve büyüme modeline eşlik eden yapısal sorunları doğru bir şekilde analiz etmek önemlidir. Türkiye ekonomisinin yapısal kısıtları borçlanmayı getirmekte, iç ve dış politika tercihlerinin yarattığı koşullar ve finans kapitale uygun bir yatırım ortamı vaat etmemesinin tetiklediği sermaye çıkışları borçlanma maliyetini arttırmıştır. Bütün bu gelişmelerin, ilk aşaması döviz kuru krizi olan zamana yayılan bir ekonomik krize yol açması kuvvetle muhtemel olduğu ileri sürülmektedir (MiSAM, 2019). Akçay (2018) yaşanan krizle ilgili üç tür açıklama çerçevesi olduğunu belirtmektedir. Birinci açıklama, krizin nedeninin siyasi olduğunu savunmakta, Cumhurbaşkanlığı Hükümet Sistemi'ne geçişi ekonomik krizin temel nedeni olarak görmekte; çözüm için parlamenter sisteme dönülmesi gerektiğini vurgulamaktadır. İkinci açıklama, krizi ‘yanlış ekonomi politikalarına' bağlamakta, buna göre krizin temel nedenini, IMF programından sapma olarak değerlendirmektedir. Bu açıklamaya göre, 2002-2008 arasındaki AK Parti'nin 'başarısı', esasında o dönemde uygulanan IMF programı sayesinde gerçekleşmiştir. Sonrasında yaşanan sorunların nedeni, siyasi iradenin IMF programını uygulamaktan vazgeçmesidir. Bu durumda, çözüm de yeni bir IMF programı ile gelecektir. Üçüncü açıklama ise krizin uluslararası ilişkilerdeki sorunlardan kaynaklandığını ileri sürmektedir. Buna göre; krizin ekonomik veya siyasi kökeni yoktur, yaşanan sorunların kökeni dışarıdadır ve Türkiye'ye yapılan ekonomik bir saldırının sonucu olarak ekonomik zorluklar yaşamaktadır. 
Bu açıklamalar medyada da karşılığını bulmuş; konu neoliberalizm konusundaki tartışmalardan daha çok uluslararası ilişkilerin politik dinamikleri ile ele alınmıştır. Ancak, medya TL'deki düşüşün enflasyonu artırmasını ve piyasa ekonomisinin kusurlarını sorgulamamış ve "ekonomik kuşatma altında" söylemini tekrarlamış, diğer ülkelerin Türkiye ekonomisini yıkma amaçlı bir "operasyon" içinde olduğunu ilan eden bu popülist söylem, kamusa tartışmalara egemen olmuştur. van Dijk'a göre (1988), haberlerin en belirgin özelliklerinden biri özel bir söylem türü oluşturması ve belirli bir sosyo-kültürel bağlamda belirli bir dil kullanımına dayanmasıdır. van Dijk (1999: 335, 367) söylem yoluyla toplumsal denetim uygulanmasının önemli bir koşulunun söylemin denetimi ve bizzat söylemin üretimi olduğunu belirtir. Bu noktada, haber metinleri kamusal iletişimde önemli bir rol oynar. İktidar sahipleri haber medyasında belirli bir anlatı yapısı içinde yer alır ve böylece iktidarları onaylanır ve meşrulaştırılır. Medya toplumsal iktidar yapılarının üretiminde ve yeniden üretiminde işlevseldir. Seçmeci kaynak kullanımı ve haber başlığının seçimi yoluyla haber medyası hangi haber aktörlerinin kamuya yeniden sunulacağına ve özellikle ne söyleneceğine karar verir.

Haber medyası toplumsal güç/iktidar yapılarının kurulduğu araçlardır. Söylem dilin kullanımına ilişkin bir kavramdır. Yönetenlerin hegemonya kurma sürecinde medya metinleri önemli bir role sahiptir. Toplumsal rıza metinsel pratikler dolayımıyla kurulmaktadır. Haber söylemi, iktidar sahiplerinin söyleminden ayrı değildir. Haberde egemen söylemler temsil edilmekte ve metin egemen söylemlerin etrafında kapanmaktadır. Haberin söylemi içinde egemen söylemler doğallaştırılmakta ve egemen ideoloji yeniden kurulmaktadır. Haberin üst söylemi burjuva ideolojisinin söylemidir (İnal, 1996). Medya metinleri, dünyayı tanımlamaya ve uygun davranış ve tutumlar için modeller oluşturmaya yardımcı olmakta ve toplumsal rolleri rolleri tasvir etmektedir. Medyanın ideolojisine dair önemli bir argüman, medyanın güçlülerin dünya görüşünü desteklediği yönündedir. Medyanın ideolojisi, medyanın söylediği ve meşrulaştırdığı değerler ilgili temel hikayelerden oluşmaktadır (Croteau ve Hoynes, 2014). Medya çalışmalarında dil ve söyleme ilişkin tartışmalar, iktidar ve güç kavramlarını ve güç/ iktidar ilişkilerinin inşasında medyanın rolünü ve anlam üretimini merkeze almaktadır.

Neoliberal mantık, pazar belirleyiciliği, metalaşma, bireyselleşme, rekabetçilik ve kişisel çıkar mantığı olarak ifade edilmekte, bu ekonomik argümanlar olumlu bir söylem içinde kurulmaktadır. Gazeteciliğin bu normatif vizyonu, "ortak çıkar" ve "milli çıkar" söylemleri etrafında bölünme ve çatışmaları birleştirmekte ve piyasa belirleyiciliğinin mantığını içselleştirmektedir (Phelan, 2014). Bu çalışmada, haber medyasının neoliberal ideolojiyi doğallaştırmasını ve neoliberalizmin ürettiği krizleri yine neoliberalizmin kavram setleriyle tanımlamasını örneklemek amacıyla Türkiye ekonomisinde yaşanan kırılganlıklar sonucunda 2018 yılında TL'nin döviz karşısında değer kaybetmesi olarak beliren döviz kuru krizinin haber medyasında nasıl temsil edildiği ve çerçevelendiği incelenmiş; neoliberal anlatıların ekonomik sorunların tanımlanma biçimine nüfuz ettiği varsayılarak sözcük seçimleri ve durum tanımları haberin söylemini belirleyen temel öğeler olarak analiz edilmiştir. 
ne şekilde sunulduğu bu araştırmanın temel çıkış noktasını oluşturmaktadır. Eleştirel yaklaşımların, haber üretiminde ideolojik etkinin baskın olduğu görüşünden yola çıkılarak araştırma örneklemi farklı ideolojik duruşları temsil eden gazetelerden oluşturulmuştur. Bu kapsamda "muhafazakâr", "solcu" ve "liberal" olarak tanımlanan üç farklı ideolojik yaklaşım üzerinden seçilen sekiz gazetenin döviz kuru krizi ile ilgili haberleri incelenmiştir. Bu çalışmada, gazetelerde yer alan haberlerin ardalanındaki ideolojik etkileri ortaya çıkarmak amacıyla, Teun van Dijk'ın haber metinlerine uyguladığı eleştirel söylem çözümlemesi yöntemini temel alarak yazılı basının döviz kuru krizi bağlamında ekonomide ortaya çıkan olumsuz tabloyu nasıl tanımladığı ele alınmış ve haberin söylem üretme pratiğine odaklanılmıştır.

\section{Kuramsal Çerçeve}

Eleştrel söylem çalışmaları, dilin toplumsal hayatı nasıl düzenlediğine odaklanmaktadır. Bu bakış açısı, söylem üretiminin iktidar ilişkilerinden bağımsız olamayacağı kabulüne dayanmaktadır. Bu noktada, van Dijk (1995: 10, 16), medyanın toplumsal, kültürel, siyasal ve ekonomik güç yapıları çerçevesinde söylem üretimindeki merkezî rolüne dikkat çekmekte ve medya gücünün öncelikli olarak okurların veya izleyicilerin zihinlerini kontrol etmede sembolik ve ikna edici bir güç olduğunu vurgulamaktadır. Eleştirel bir bakış açısı içinde, medyanın gücüne ilişkin analizler daha çok gücün kötüye kullanım biçimlerine gönderme yapmakta, örneğin, medya gücünün bir pratiği olarak manipülasyon genellikle olumsuz terimlerle değerlendirilmektedir. Bilginin stratejik kontrolü aynı zamanda söylem anlayışının kontrolünde önemli bir unsurdur. Tutumları kontrol etmek, kitle iletişim söylemlerinin yanı sıra konuları ve anlamları da kontrol etmeyi gerektirmektedir.

Söylem, dilin kullanımı ve dil yoluyla tezahür eden ideolojilerin oluşturduğu kültürlere atıfta bulunmak için kullanılırken, söylem çözümlemesi dili çeşitli şekillerde ele almakta ve araştırmaktadır. Bu anlamda söylem, kültürel ve değer taşıyan bir anlamlandırma sistemidir. Söylem, bireylerin toplumla etkileşimlerini şekillendirmenin yanı sıra toplumsal düzeni ve bilgiyi de oluşturmaktadır (Scharp ve Thomas, 2017). Söylem, sosyal ve politik gerçekleri oluşturan ve onlar tarafından oluşturulan bir pratiktir. Söylemsel eylemler toplumsal koşulların oluşumunda ve inşasında belirleyici bir rol oynamakta, statükoyu meşrulaştırmakta, devam ettirmekte ve dönüştürmektedir (Barker ve Galasiński, 2001).

van Dijk (2011: 3-4) söylemi yapısal, bilişsel ve toplumsal olarak üç yönüyle kategorize etmiştir. Söylem, güç ve güç kullanımı ile yorumlanıp yeniden üretilen toplumsal düzenin temel yönlerinden biri olarak toplumsal gruplar veya örgütler tarafından kamusal söylemlere tercihli bir şekilde erişme ve onları kontrol etmeyi içermektedir. Dil kullanıcılarının zihnini kontrol etmenin karmaşık bir süreci ve dolaylı olarak bu zihinsel temsillere dayanan eylemler aracılığıyla söylem bir yandan toplumsal eşitsizliğin önemli bir koşulu, diğer yandan karşı güç biçimleri olarak önemli bir direniş ve muhalefet aracı olmaktadır. Bu özelliği, toplumun siyasal düzeninde söylemin rolününe işaret etmekte 
ve söyleme eleştirel sosyo-politik yaklaşımla açıklanmaktadır.

Fairclough (2003) söylem çözümlemecilerin yeni kapitalizme ilişkin toplumsal araştırmalara katkıda bulunacağını belirtir ve özellikle Dünya Bankası (WB) ve Uluslarası Para Fonu (IMF) gibi ulusüstü kuruluşlar aracılığıyla yayılan küresel söylemelere ve dilin çağdaş sosyo-ekonomik değişikliklerde oynadığı role dikkat çeker. Fairclough'un (2003a:2) yaklaşımı, dilin diyalektik olarak toplumsal hayatın indirgenemez bir parçası olduğu. toplumsal yaşamın diğer unsurları ile iç içe geçtiği varsayımına dayanmaktadır. Böylece, toplumsal araştırma her zaman dili dikkate almak zorundadır. Söylem analizi kullanarak dil üzerine odaklanmak toplumsal araştırma yapmanın verimli bir yoludur. Buradaki temel sorun toplumsal hayatı dile indirgeyerek her şeyin söylem olduğunu söylemekten çok, söylem çözümlemesini diğer çözümleme biçimleriyle bağlantılı olarak kullanmaktır.

Dil bir temsil sistemi olarak çalışır. Diğer insanları, kavramlarımızı, fikirlerimizi ve hislerimizi temsil etmek için işaretler ve semboller kullanılır. Dil, düşüncelerin, fikirlerin ve duyguların bir kültürde temsil edildiği ortamlardan biridir. Bu nedenle temsil, dil aracılığıyla anlamın üretildiği süreçlerin merkezidir (Hall, 2013). Hall (2013), ayrıca, anlamın oluştuğu bir kültür çemberinden söz eder (circuit of culture). Kültür çemberinde anlam birkaç farklı alanda ve süreçte üretilir. Bunlar birbiriyle döngüsel bir etkileşim halinde olan temsil, kimlik, üretim, tüketim ve düzenleme gibi pratiklerdir. Anlam, katıldığımız her kişisel ve sosyal etkileşimde sürekli üretilmekte ve değiş tokuş edilmektedir. Anlam sorunu, kültürel devremizdeki tüm farklı anlara veya uygulamalara bağlı olarak ortaya çıkar. Dil temsil yoluyla çalışmaktadır. Dilin kullanımının ve söylemin nasıl çalıştığı, toplumsal ve kültürel bilimlerdeki "söylemsel dönüş" yaklaşımının temel konusunu oluşturmaktadır.

Eleştirel söylem çalışmaları, dili bir sosyal pratik olarak görmekte ve dil kullanımının içeriğine önem atfetmektedir. Söylemin sosyal pratik olarak tanımlanması, belirli bir söylemsel olay ile durumlar, kurumlar ve sosyal yapılar arasında diyalektik bir ilişki anlamına gelmektedir. Yani, söylem sosyal olarak kurucu olduğu kadar koşulludur. Söylem insanlar ve insanlar grupları arasındaki durumları, bilgi objelerini ve sosyal kimlikleri ve ilişkileri oluşturur ve önemli güç sorunlarına yol açar. Söylemsel pratikler büyük ideolojik etkilere sahiptir ve bunlar sosyal sınıflar, kadınlar ve erkekler ile etnik / kültürel çoğunluklar ve azınlıklar arasındaki eşit olmayan iktidar ilişkilerini, insanları temsil etmeleri ve konumlandırmaları yoluyla üretmeye ve yeniden üretmeye yardımcı olmaktadır. Eleştirel söylem çalışmaları yaklaşımı, söylemi sosyal hayatın organizasyonuna ve yapılandırımasına hizmet eden dilin göreli istikrarlı kullanımı olarak ele almaktadır (Wodak ve Meyer, 2016). Wodak ve Meyer (2016:13) eleştirel söylem çalışmalarının odaklandığı temel araştırma gündemlerini ve sınırıııklarını altı grupta incelemiş; bunları, neoliberalizmin, küreselleşmenin, iklim değişikliğinin, dijital iletişim teknolojilerinin kullanımının etkisini açıklamak, anlamak ve analiz etmek; ayrıca, bilişsel bilimlerden gelen yaklaşımları eleştirel söylem çalışmalarına entegre etmek ve tarihsel süreçlerle hegemonik anlatılar arasındaki ilişkiyi anlamak ve analiz etmek şeklinde kategorize etmiştir. 
Eleştirel söylem çözümlemesi söylemi daha geniş yapısal ve ideolojik güçlerin bir yansıması olarak incelemekte, azınlık veya göreceli olarak güçsüz grupların söylem dezavantajlarını ortaya çıkarmak açısından önemli bir metodolojik katkı sağlamaktadır (Wooffitt, 2005). Toplumsal olarak paylaşılan bilgi, davranışlar, kurallar ve değerler bilişsel bileşenleri oluşturmaktadır. Söylemin ideolojik yapıları olan kutuplaşma, zamirler (bizler, onlar), kategorize etmeler, kendini pozitif ve ötekini negatif olarak sunmalar, değerler ve çıkarlar söylemsel hakimiyeti yansıtmaktadır (van Dijk, 2016). Söylemler belirli bir bağlamda söylenme(me)si gereken, kullanımda olan, ancak açık bir şekilde ifade edilmeyen çerçevelerdir. Söylem çözümlemesi, metinlerin fikirsel yönlerini incelemek için kullanılmaktadır (Bergström ve Boréus, 2017).

\section{Literatür İncelemesi}

Ekonomik konuların haber kapsamı, aynı zamanda ideolojik bir yeniden üretme içermektedir. Ekonomi haberlerinin çoğu iş dünyası ile ilgilidir. Bireyler ekonomik hayatta çeşitli ekonomik roller (işçi, tüketici, vatandaş veya yatırımcı) üstlenmekle birlikte, ekonomi haberleri ağırıklı olarak yatırımcıların faaliyetlerine odaklanmaktadır. Sonuç olarak, ekonomi haberleri büyük ölçüde iş haberleridir ve iş haberleri kurumsal aktörlere ve yatırımcılara yöneliktir. Bu tür bir haberde, borsadaki iniş ve çıkışlar genellikle ülkenin ekonomik sağlığının bir göstergesi olarak hizmet veren merkezler olarak konumlandırılmakta, ekonominin sağlığı yatırımcıların serveti ile eşitlenmektedir. Bu tanımlar, farklı toplumsal grupların farklı ekonomik çıkarlara sahip olabileceğini kabul edememektedir. Örneğin, borsada bir yükseliş ülke için olumlu bir ekonomik haber olarak gösterilirken, kurumsal kârlıııtaki bir artış kapsamlı işten çıkarmaların ardından verimlilik artışının bir sonucu olabilmektedir. Haberler, işgücü piyasasının karmaşıklığını araştırsa bile, genellikle değişen işveren-çalışan ilişkileri veya işten çıkarılan işçilerin deneyimlerinin uzun vadeli sonuçlarına çok daha az yer vermektedir. Haber medyasının kurumsal ve yatırımcı perspektifine daha fazla vurgu yapması iş dünyasının ekonomik haberlerin kapsamındaki hakimiyetini doğallaştırmakta ve ekonominin sağlığı yatırımcının çıkarları ile eşdeğer tutulmaktadır (Croteau ve Hoynes, 2014: 164-165).

Son yıllarda finansal krizlerin ve ekonomik olayların haber medyasında nasıl yer aldığın ilişkin çok sayıda araştırma yapılmıştır. Batı'da özellikle 2008 ekonomik krizinden sonra bu konuya ilginin arttığı ve ekonomik sorunların haber medyasında nasıl çerçevelendiği incelenmiştir. Medya, ekonomik dünyayı hisse ve varlık fiyatları, yatırım ve zenginlik gibi konulardan ibaret gördüğü, ekonomik gerçeklikleri dışladığı, kriz öncesinde ve sırasında ekonomi alanındaki suistimalleri belirlemediği ve "bekçi köpeği" rolünü yerine getirmediği gerekçesiyle eleştirilmiştir. Örneğin, medya özellikle yoksul insanların ev almalarından ve inşaat sektöründeki yükselmeden sözederken, mortgage piyasasındaki kötüye kullanımları görmezden gelmektedir. Medya piyasadaki kaynaklarına çok yakın olması nedeniyle bekçi köpeği olarak hizmet vermemekle, ekonomi gazetecileri ekonomi okuryazarı olmamakla ve kısa dönemli eğilimlere odaklanmakla eleştirilmektedir. Medya ekonomistlerden nadiren alıntı yapmakta 
ve en temel makroekonomik ilkeleri kavramada yeteresiz kalmakta, dolayısıyla piyasa kaynaklarının açıklamalarına bağlı olmakta ve bunun sonucunda iş dünyasını destekleyen görüşleri yaymaktadır (Schiffrin, 2015).

Temple (2015) İngiletere'deki finansal krizin haber kapsamını incelemiş, krizden etkilenen toplumsal grupların daha çok tüketici ve üretici kimlikleriyle sunulduğunu göstermiştir. Krizin, durgunluğun veya kemer sıkmanın bireyler üzerindeki etkisi verimlilik veya harcama güçleri açısından çerçevelenmiştir. Bireyleri "piyasa vatandaşları" olarak gösteren bu temsil biçimi neoliberal anlatıya dayanmakta ve bu anlatı biçimi İngiltere medyasının egemen söylemini oluşturmaktadır. Bu ideolojik çerçeve toplumsal söylem üzerinde de belirleyici bir etki yaratmaktadır. Berry (2019) de 2018 finansal kriziyle ilgili olarak İngiltere'nin ekonomik tarihindeki bu kilit dönemde kitle iletişim araçlarının kamuoyunu ve politik olayları nasıl etkilediğini analiz etmiş, bir kemer sıkma politikasının nasıl kabul edilebilir hale geldiğini ve bankaların bu durumdan nasıl kurtulduğunu tartışmış ve ekonomi gazeteciliğinin zayıf yönlerini tartışmıştır.

Günümüzde sermayenin kontrolünde olan medyanın kamusal sorumluluk anlayışından uzaklaştığı ve ekonomik eşitsizlikleri haber konusu yapmadığı görülmektedir. Neoliberalizmin kamu sektörünü radikal bir biçimde dönüştürmesiyle birlikte özellikle yayıncılık alanı olmak üzere pek çok alanda kamu hizmeti ve kamu yararı anlayışı da terk edilmiş, medya sermayesi tekelleşme ve uluslararasılaşma yönünde bir eğilim içinde olmuştur. Ekonomi haberlerinde sendikalar, işçi hakları, sosyal güvenlik, yoksulluk gibi konular yerine iş ve finans dünyası, kamu-özel sektör işbirliği gibi daha çok sermaye kesimine yönelik konulara yer verilmektedir. Ekonomi haberlerinin çerçevesi, medyanın ekonomik ve sosyal haklara odaklı çoğulcu ve eşitlikçi bir anlayışı dışladığını ve neoliberal ideoloji ile uyumlu olduğunu göstermektedir (Şen ve Avşar, 2012). Şen ve Avşar (2012) anaakım medyanın ekonomi haberlerini incelemiş ve ekonomi haberlerinde iş dünyası ve sermaye yatırımları ile ilgili haberlerin ağırıklı olarak yer aldığını ortaya koymuşlardır. Haberlerde işlenen konular kadar öne çıkarılan ve görüşlerine yer verilen aktörlerin kimler olduğu da haberin ürettiği egemen anlamları ve ideolojiyi göstermesi açısından önemlidir. Konu dağılımına paralel olarak aktörlerin dağılımı da toplumdaki güç ve iktidar ilişkilerini yansıtmaktadır. Siyasî iktidarın ve sermaye sınıfının temsilcileri haberlerde görüşlerine öncelik verilen durum tanımlayıcıları olarak seçilmekte; haberler, onların eylem ve söylemleri üzerine inşa edilmektedir.

\section{Araștırmanın Yöntemi}

Söylem genellikle ideolojileri doğrudan ifade etmemekte, ancak sosyal meseleler hakkındaki belirli grup tutumları ve belirli olaylarla ilgili kişisel görüşler ve konuşmacıların veya yazarların, yani kişisel bağlam modellerinin öznel olarak ifade ettiği iletişimsel durumun etkisi altında oluşmaktadır. Bu tür bağlam modelleri, altta yatan ideolojik inançları hafifletebilmekte veya büyütebilmektedir. Altta yatan ideolojiler (ve onlar tarafından etkilenen sosyal tutumlar ve kişisel görüşler) genellikle kutuplaştırıldığından, 
bu ideolojik söylem "biz"i (topluluk içi) olumlu, "onlar"ı (dışarıdaki grup) da olumsuz temsil içinde vurgulayarak ve bunun sonucu olarak "biz"in olumsuz, "onlar"ın da olumlu temsilini hafifleterek işlemektedir. van Dijk, bu genel söylemsel strateji kombinasyonunu "ideolojik kare" olarak adlandırmaktadır (2009: 194). Kutuplaşmış (biz ve onlar karşıtlığı) ideolojiler, mevcut güç yapılarını sürdürmek için toplumun temel boyutları ile uyum içindedir. Bu nedenle, kamusal söylemi ve özellikle de kitle iletişim araçlarının içeriğini kontrol eden seçkinler, böylece, güçlerini sürdürmeye yardımcı olan ideolojilerin oluşumunu ve çoğalmasını da kontrol etmektedir. Haberin ideolojisinin ve diğer sembolik seçkinlerin söylem biçimlerinin detaylı bir şekilde incelenmesi haber medyasının toplumdaki ideolojilerin (yeniden) üretilmesindeki rolünü göstermektedir (van Dijk, 2009: 202).

Bu araştırmada ideolojilerin haberin söylemini nasıl etkilediğini göstermek ve haberdeki ideolojik mücadeleyi ortaya çıkarmak amacıyla farklı siyasal eğilimleri temsil eden gazetelerin 1 Temmuz-31 Ekim 2018 tarihleri arasındaki TL krizi ile ilgili haberleri incelenmiştir. Bu kapsamda; "ekonomik çöküş", "ekonomik darboğaz", "enflasyonla mücadele", "dış güçlerin oyunu" ve "ekonomik kriz" anahtar kelimeleri ile taranan 414 adet habere ulaşılmıştır. Böylelikle, haber medyasının ekonomik sorunları tanımlama biçimi üzerinden ideolojik anlamların nasıl kurulduğu belirlenmeye çalışılmış ve farklı ideolojik görüşleri yansıtan sekiz gazete örneklem olarak alınmıştır.

Bu kapsamda; merkez sağ-liberal Hürriyet, hükümet yanlısı-merkez sağ Sabah ve Star, muhafazakâr-İslamcı Yeni Şafak ve Yeni Akit gazeteleri ile merkez-sol ve Atatürkçü Cumhuriyet ve Sözcü gazeteleri ve radikal sol Birgün gazetesi incelenmiş ve bu gazetelerin Türk Lirası döviz kuru krizinden kaynaklanan ekonomik sorunları ve mevcut ekonomik durumu nasıl tanımladıkları ve ne şekilde çerçeveledikleri çözümlenmeye çalışıımıştır. Çalışma, 1 Temmuz- 31 Ekim 2018 tarihleri arasındaki dört aylık bir dönemi kapsamış ve bulgulardan elde edilen sonuçlar örneklemle sınırlı tutulmuştur. TL'deki sert düşüşün bu dönemde daha belirgin olması nedeniyle bu zaman dilimine odaklanılmıştır. Bu bağlamda, "ekonomik darboğaz", "ekonomik çöküş", "dış güçlerin oyunu", "enflasyonla mücadele" ve "ekonomik kriz" gibi anahtar sözcükler üzerinden haber medyasındaki söylemsel farklılaşma ve egemen ideolojinin söylemsel pratikler yoluyla işleyişi tespit edilmeye çalışıımıştır. Çözümleme kategorilerinin belirlenmesinde van Dijk'ın haber şeması temel alınmıştır (1986; ayrıca bkz. Özer, 2018: 166). Buna göre, van Dijk'in makro yapı kategorisi çerçevesinde haberin tematik ve şematik unsurları incelenmiştir. van Dijk'ın geliştirdiği makro yapı kategorileri şu şekildedir:

1. Tematik Yapı

a. Başlıklar

b. Haber Girişleri ( Spot veya haber metninin ilk paragrafı)

c. Fotoğraf

2. Şematik Yapı

a. Durum ( Ana olayın sunumu, sonuçlar, ardalan bilgisi, bağlam bilgisi)

b. Yorum ( Haber kaynakları, olay taraflarının olaya getirdikleri yorumlar) 
Eleştirel söylem çözümlemesine ek olarak haberlerin frekans dağılımına ilişkin nicel veriler elde etmek amacıyla içerik çözümlemesi yönteminden de yararlanılmıştır.

Araştırma soruları şu şekildedir:

1. Medya, ekonomik krizle ilgili durum tanımını kapitalist söylem ve değerlerin yeniden üretimi çerçevesinden mi yapmaktadır?

2. Medya ekonomik durumu nasıl tanımlamakta ve siyasal iktidarın söylemini yeniden mi üretmektedir?

\section{Bulgular ve Tartıșma}

Verilerin sunumunda önce içerik çözümlemesinden elde edilen nicel veriler analiz edilmiş ardından eleştirel söylem çözümlemesine ilişkin bulgular yorumlanmıştır.

\section{1. İcerik Çözümlemesi}

\section{Gazetelere Göre Haberlerin Dağılımı:}

Tablo 1'de ekonomik kriz ile ilgili haberlerin gazetelere göre dağılımı verilmektedir. Haberlerin kapsamı bir konunun ne sıklıkta yer aldığını göstermesi ve konunun gündemde tutulması açısından önemli bir göstergedir.

Tablo 1. Gazetelere Göre Haberlerin Dağılımı (1 Temmuz-31 Ekim 2018)

\begin{tabular}{|l|c|c|}
\hline Gazete & Frekans & Yüzde \\
\hline Birgün & 87 & $\% 21,01$ \\
\hline Cumhuriyet & 81 & $\% 19,57$ \\
\hline Hürriyet & 37 & $\% 8,94$ \\
\hline Sabah & 24 & $\% 5,80$ \\
\hline Sözcü & 85 & $\% 20,53$ \\
\hline Star & 39 & $\% 9,42$ \\
\hline Yeni Akit & 30 & $\% 7,25$ \\
\hline Yeni Şafak & 31 & $\% 7,49$ \\
\hline Toplam & 414 & $\mathbf{1 0 0 , 0}$ \\
\hline
\end{tabular}


Haberlerin dağılımına bakıldığında, konu ile ilgili en fazla haber Birgün (87), Sözcü (85) ve Cumhuriyet (81) gazetelerinde yayımlanmıştır. Bu gazetelerin sol ve muhalif çizgide olmaları, ekonomide yaşanan olumsuz gelişmelerin sorumlusu olarak hükümeti görmeleri ve hükümetin ekonomi politikalarını eleştirmeleri nedeniyle TL döviz kurunda yaşanan düşüşü ve bununla bağlantılı ekonomik tabloyu tartışmışlardır. Bu gazetelerin haber sayılarının fazla olması, konunun gündemde tutulmak istenmesi ile açıklanabilir. Haber dağılımlarında, dördüncü sırada yer alan Star Gazetesi (39)'ni sırasıyla Hürriyet (37), Yeni Şafak (31), Yeni Akit (30) ve Sabah (24) takip etmektedir. Muhafazakâr ve hükümet yanlısı medya olarak ele aldığımız Star, Yeni Akit ve Yeni Şafak gazetelerindeki haberlerin içeriğine bakıldığında daha çok "enflasyonla mücadele" başlığında yoğunluk gösterdiği görülmektedir. Bu durum da ideolojik olarak hükümet politikalarına destek vermeye yönelik bir yaklaşım içinde olmaları ile açıklanabilir.

Anahtar Sözcüklere Göre Haber Dağılımı:

Ekonomik kriz ile ilişkili haberler taranırken "ekonomik kriz" ile birlikte"ekonomik çöküş", "ekonomik darboğaz", "dış güçlerin oyunu" ve "enflasyonla mücadele" anahtar sözcükler kullanılmıştır. Araştırma için belirlenen anahtar sözcüklerin kullanım sıklığı da haberin söylemini göstermesi açısından önemlidir. Aşağıda verilen Tablo 2'de belirlenen anahtar sözcüklere göre haber dağılımları verilmektedir.

Tablo 2. Anahtar Sözcüklere Göre Haber Dağılımı

\begin{tabular}{|l|c|c|c|c|c|}
\hline Gazete & $\begin{array}{c}\text { Dış Güçlerin } \\
\text { Oyunu }\end{array}$ & $\begin{array}{c}\text { Ekonomik } \\
\text { Çöküş }\end{array}$ & $\begin{array}{c}\text { Ekonomik } \\
\text { Darboğaz }\end{array}$ & $\begin{array}{c}\text { Ekonomik } \\
\text { Kriz }\end{array}$ & $\begin{array}{c}\text { Enflasyonla } \\
\text { Mücadele }\end{array}$ \\
\hline Birgün & 19 & 5 & 14 & 46 & 3 \\
\hline Cumhuriyet & 22 & 6 & 5 & 43 & 5 \\
\hline Hürriyet & 13 & 2 & 0 & 10 & 12 \\
\hline Sabah & 5 & 3 & 0 & 4 & 12 \\
\hline Sözcü & 30 & 3 & 4 & 38 & 10 \\
\hline Star & 9 & 2 & 0 & 6 & 22 \\
\hline Yeni Akit & 15 & 0 & 0 & 3 & 12 \\
\hline Yeni Şafak & 6 & 2 & 0 & 7 & 16 \\
\hline Toplam & $\mathbf{1 1 9}$ & $\mathbf{2 3}$ & $\mathbf{2 3}$ & $\mathbf{1 5 7}$ & $\mathbf{9 2}$ \\
\hline
\end{tabular}

Yukarıda verilen tablo sonuçlarına bakıldığında ilk olarak dikkat çeken merkez sağ ve muhafazakâr gazetelerde "ekonomik darboğaz" kavramının yer aldığı haberlerin bulunmamasıdır. "Ekonomik darboğaz", olumsuz bir tonlama içerdiğinden bu tanımlama iktidar partisinin politikalarını eleştirmek anlamına gelecektir. Diğer gazetelere bakıldığında sol eğilimli gazetelerin bu başlığa yer verildiği görülmektedir. Diğer taraftan, olumsuz ekonomik durumu "enflasyonla mücadele" çerçevesinde haberleştiren gazeteler ise ağırıklı olarak muhafazakâr ve hükümeti destekleyen gazetelerdir. Kavramlar ve tanımlamalar üzerinden söylem inşa edilmektedir. 
Haberin Yeri:

Bir gazetede haberin yer aldığı sayfa ve kapladığı alan da haberin öne çıkarılmasında önemli unsurlardan biridir. Bu amaçla aşağıda verilen Tablo 3'te ekonomik durum ile ilişkili haberlerin yer aldığı bölümlere yönelik sonuçlara yer verilmiştir.

Tablo 3. Haberin Yeri

\begin{tabular}{|l|c|c|c|}
\hline Gazete & ilk Sayfa & $\begin{array}{c}\text { ilk Sayfa+ } \\
\text { iç Sayfa }\end{array}$ & íç Sayfa \\
\hline Birgün & 0 & 45 & 42 \\
\hline Cumhuriyet & 0 & 43 & 38 \\
\hline Hürriyet & 0 & 16 & 21 \\
\hline Sabah & 0 & 10 & 14 \\
\hline Sözcü & 0 & 41 & 44 \\
\hline Star & 0 & 16 & 23 \\
\hline Yeni Akit & 0 & 8 & 22 \\
\hline Yeni Şafak & 0 & 11 & 20 \\
\hline Toplam & $\mathbf{0}$ & $\mathbf{1 9 0}$ & $\mathbf{2 2 4}$ \\
\hline
\end{tabular}

Yukarıda verilen dağılıma göre genel olarak verilen haberler iç sayfalarda yoğunlaşırken, ilk sayfadan yönlendirmeli olarak iç sayfalarda yer alanların sayısı da oldukça fazladır. $\mathrm{Bu}$ haberlerin içeriğine bakıldığında ise sağ-muhafazakâr gazetelerin "dış güçlerin oyunu" ve "enflasyonla mücadele" başlıklarının geçtiği haberleri ilk sayfadan verirken, sol eğilimli gazetelerin ise "ekonomik kriz" başlığına genel olarak ilk sayfadan yer verdiği görülmüştür. Ekonomide yaşanan olumsuz gelişmeler, iki farklı perspektifle okuyucuya sunulmuştur. Haber anlatılarında keskin bir kutuplaşma göze çarpmaktadır.

Haber İçeriğinin Türü:

Çalışma kapsamında taranan haberlerin yoğunluğuna göre içerikler haber ve köşe yazısı olarak gruplandırılmıştır. Aşağıda verilen Tablo 4'te bu gruplandırmaya yönelik sonuçlar yer almaktadır. Köşe yazıları kanaat önderlerinin değerlendirmelerini yansıtan ve yorum içeren metinler olması bakımından kamuoyu oluşturma potansiyeli taşımakta ve söylem üretiminde önemli bir rol oynamaktadır. 
Tablo 4. Gazete İçeriğinin Türü

\begin{tabular}{|l|c|c|}
\hline Gazete & Haber & Köşe Yazısı \\
\hline Birgün & 70 & 17 \\
\hline Cumhuriyet & 65 & 16 \\
\hline Hürriyet & 32 & 5 \\
\hline Sabah & 20 & 4 \\
\hline Sözcü & 56 & 29 \\
\hline Star & 31 & 8 \\
\hline Yeni Akit & 21 & 9 \\
\hline Yeni Şafak & 22 & 9 \\
\hline Toplam & $\mathbf{3 1 7}$ & $\mathbf{9 7}$ \\
\hline
\end{tabular}

Metinlerinin türüne göre yapılan analiz sonucunda, medyanın ekonomik krize ilişkin daha çok haber türüne yer verdiği görülmüştür. Taranan köşe yazılarının içeriğine bakıldığında ise sol eğilimli köşe yazarlarının hükümetin ekonomi politikasını eleştirdikleri, muhafazakâr ve liberal köşe yazarlarının ise hükümetin ekonomi politikalarını destekledikleri ve dış güçlerin etkisine vurgu yaptıkları görülmüştür.

\subsection{Eleștirel Söylem Çözümlemesi:}

\subsubsection{Tematik Yapı}

Haber Başlıkları:

Okuyucuya sunulan bir haberde ilk olarak dikkat çeken kısım başlıktır. Okuyucunun ilgisini çeken bir başlık habere olan ilgiyi artırıaktadır. Başlık, algı ve dikkat süreçlerini etkileyen önemli bir unsurdur. van Dijk'a göre bir başlık, haberin üst makro açıklamalarının bir parçasını ifade etmiyorsa ve düşük seviyede detay içeriyorsa, başlığın ön yargılı olduğu sonucuna varmak mümkündür (1986: 161).

Aşağıda verilen seçilmiş örnek haber başlıkları şöyledir:

“Türk ekonomisi patinaj yapıyor” ( Sözcü, 31 Ekim 2018)

"Ekonomide milli dönüşüm” ( Star, 23 Ekim 2018)

"Tasarruf hatırlandı" (Cumhuriyet, 25 Temmuz 2018)

“Tüketicinin \%82'si kriz var diyor” ( Sözcü, 25 Eylül 2018)

"Borsa 4 ayın en yükseğinde" ( Yeni Şafak, 28 Eylül 2018)

"Sarayda yük ve israf halkta borç yükü var" ( Birgün, 25 Eylül 2018)

“Ekonomik kriz yok manipülasyon var” ( Yeni Şafak, 7 Ekim 2018)

"Enflasyona karşı tek yumruk olduk” ( Star, 16 Ekim 2018)

“Ekonomide İstiklal Savaşı veriyoruz" (Yeni Akit, 11 Ağustos 2018) 
“Ekonomide 15 Temmuz ruhu şaha kalktı” (Sabah, 14 Ağustos 2018)

“ İkinci çeyrekte 5.2 büyüdük” (Hürriyet, 11 Eylül 2018)

"Amaçları yarım kalan ihaneti tamamlamak" (Sabah, 11 Ağustos 2018)

“Ümmetten Türkiye'ye dua ve destek” (Yeni Akit, 17 Ağustos 2018)

“ ‘Krizin nedeni dış güçler değil’ “, (Birgün, 15 Ağustos 2018)

"Prof. Dr. Aykut Lenger: Kriz Kaçinilmazdi, Yangin Sürecek" (Cumhuriyet, 15 Ağustos 2018)

Yukarıda verilen haber başlıklarına bakıldığında gazetelerin ideolojik yaklaşımlarının genel olarak haber sunum biçimine yansıdığı görülmektedir. Anaakım ve muhafazakâr gazetelerin kullandığı başlıklarda genel olarak vurgulanan temanın milliyetçilik olduğu görülmektedir. Milliyetçilik üzerine yoğunlaşan haberlerde Türkiye kurbanlaştırılarak sunulmakta ve ülkenin ekonomik bir saldırı altında olduğu ileri sürülmektedir. Burada yaşanan ekonomik sıkıntı göz ardı edilmezken, sorumlunun hükümet olmadığını empoze etmeye yönelik bir retorik kullanılmaktadır. Hükümet politikalarını destekleyen bu haberlerde ekonomiye darbe vuran "onlar" ve mağdur olan "biz" şeklinde bir yaklaşım vardır. "Biz"e dair dini ve milli değerler etrafında toplanma vurgusu yapılmaktadır. Özellikle, "tek yumruk", "İstiklal Savaşı", "15 Temmuz ruhu" ve "ihanet" gibi metaforlarla bu anlatı biçimi desteklenmekte ve yaşananın bie konomik kriz değil, bir "manipülasyon" olduğu vurgusuyla da gerçeklik yeniden tanımlanmaktadır.

"Sol eğilimli" gazetelerin haber sunumlarına bakıldığında ise, karşıt bir söylemin ön plana çıktığı görülmektedir. Özellikle, "tasarruf", "israf”, "borç yükü” ve "patinaj” gibi sözcük seçimleriyle ekonominin içinde buluduğu durum olumsuz bir çerçevede sunulmuştur. Ekonomik krizin yaşandığına yönelik haberler verilirken burada uzman görüşlerine yer verilerek bir uslamlama yapılmakta ve hükümet eleştirisi rasyonel bir temele dayandırılmıştır. Örneğin, Cumhuriyet gazetesi bir akademisyenin, Birgün gazetesi de bir sivil toplum kuruluşunun durum tanımlarını kullanmıştır.

Spotlar (Haber Girişleri):

Haberin özetini oluşturan spotlar, söylem çözümlemesinde incelenmesi gereken önemli bölümlerden biridir. Bu bakımdan, yukarıda başlıkları verilmiş olan haberlerin giriş bölümleri incelenmiştir.

"Bütçe görüşmelerinde konuşan MHP'li Kalaycı bu tespiti yaptı, "Halk fakirleşti" dedi” (Sözcü, 31 Ekim 2018)

"Savunma Sanayii alanında başlatılan 'millileşme' hamlesi, ekonomi ve üretim alanında da kendini göstermeye başladı. Yerli hammaddeli dev yatırımlar, cari açığı azaltırken ihracatı rekora taşıdı" (Star, 23 Ekim 2018)

"Ekonomistlerin ardından iş dünyası ile bir araya gelen Albayrak, yeni OVP (orta vadeli plan) için görüş alışverişinde bulunarak, enflasyon ve tasarruf mesajı verdi" (Cumhuriyet, 25 Temmuz 2018) 
"Ekonomideki spekülatif kara bulutlar dağıldı. Dün yüzde 1, 16 değer kazanarak 100. 298 puanı gören Borsa, son 4 ayın en yüksek kapanışı yaptı. Düşüşünü sürdüren dolar ise 5, 98 TL'yi gördü" (Yeni Şafak, 28 Eylül 2018)

"Küresel eşkıyanın "papaz" üzerinden ekonomik savaş başlatmasına, "boyun eğmeyiz" mesajı veren iş dünyası, 15 Temmuz'da silahlara karşı gösterilen "milli duruş"un, ekonomik savaş karşısında da gösterileceğini açıkladı" ( Yeni Akit, 11 Ağustos 2018)

"Ekonomik saldırıya kalkışan hanet odaklarına en güzel yanıtı, milli birlik ruhuyla kenetlenen vatandaşlar verdi. Başkan Erdoğan'ın çağrısıyla tüm yurtta dolar bozdurma yarışı başladı. İstanbul'da TÜMKIAD üyeleri 3 milyon dolar, Kocaeli'nde iki gurbetçi 85 bin euro bozdurdu. Bolu'da da pazarcılar dolar bozdurandan para almadı" (Sabah, 14 Ağustos 2018)

"Türkiye ekonomisi, 2018'in ikinci çeyreğinde beklentilere uygun şekilde yüzde 5. 2 oranında büyüdü" (Hürriyet, 11 Eylül 2018)

Yukarıda örnekleri sunulan haber girişlerinde söylemsel farklılaşmanın belirginleştiği görülmektedir. Özellikle, muhafazakâr ve liberal gazetelerin "büyüme”, "rekor”, "kara bulutların dağılması" ve "milli duruş" gibi olumlu çağrışımsal kavramlar üzerinden ekonomik krizin olmadığı ve krizin aşıldığı yönünde bir söylem ürettikleri görülmektedir.

\subsection{2. Șematik Yapı: Durum Çözümlemesi}

Bu bölümde ana olayın sunumu, sonuçlar, ardalan ve bağlam bilgisi incelenmiştir. Ana olay kategorisinde, habere konu olan olaylar hakkındaki tüm bilgi düzenlenmekte; bu bilgi, elit aktör, olumsuzluk, coğrafi ve ideolojik yakınlık gibi haber değerlerine dayanmakta ve gerçek olaya kısıtlamalar getirmektedir. Bağlam, haberdeki ana olayın gerçek durumu hakkındaki tüm bilgiyi kapsamaktadır. Bunlar, genellikle sosyo-politik durumları içermektedir. Geçmiş olaylar ile tarih kategorisini de birbirinden ayırmak gerekmektedir. Tarih, aylar ve yıllar öncesine uzanmakta, geçmiş olaylardan farklı olarak ana olayın nedenlerine odaklanmamaktadır. Bağlam, haberdeki ana olayın gerçek durumu hakkındaki tüm bilgiyi kapsamaktadır. Bunlar, genellikle sosyo-politik durumları içermektedir (van Dijk, 1986: 163-165).

Yeni Akit Gazetesi, "Ekonomide İstiklal Savaşı Veriyoruz", 11 Ağustos 2018

"Küresel eşkıyanın "papaz" üzerinden ekonomik savaş başlatmasına, "boyun eğmeyiz" mesajı veren iş dünyası, 15 Temmuz'da silahlara karşı gösterilen "milli duruş"un, ekonomik savaş karşısında da gösterileceğini açıkladı.

DEVLETIMIZE GÜVENIMIZ TAM i MÜSIAD Başkanı Abdurrahman Kaan...

OYUNU BOŞA ÇIKARACAĞIZ i iTO Başkanı Şekib Avdagiç...

BU SINAVI DA ATLATIRIZ I i ASKON Başkanı ...( Manşetten verilen bölüm).

"Dik Duracağız Ekonomik Savaşı Kaybetmeyeceğiz"

Spekülatörlerin kur üzerinde oyun kurduğu saatlerde Hazine ve Maliye Bakanı Berat Albayrak, 'Yeni Ekonomik Modeli' açıklayarak Türkiye'nin kararlılıkla ve disiplinli olarak yoluna devam edeceğini söyledi. 'Döviz kuru'na değil 'ekonomi'ye 
odaklandıkları mesajı veren Bakan Albayrak'ın açıklamalarını yakından takip eden iş dünyası da yeni döneme tam destek verdi..."

Yeni Akit Gazetesinin haberlerinden birinin başlığında "İstiklal Savaşı" ibaresi kullanılması ile tarihsel bir özdeşlik kurulmaktadır. Geçmişte yaşanılan ve başarıyla atlatılan bir durum ile ekonomik kriz eş anlamlı tutularak konu bir milli mücadeleye dönüştürülmüştür. Haberin giriş kısmında kullanılan "küresel eşkıya" tanımlaması ile yapılan aktör tanımı ABD’yi veya Trump'ı "onlar" kategorisinde değerlendirmekte ve "biz"im karşımıza yerleştirmekte ve düşman olarak göstermektedir. Haberin manşette verilen bölümünde otoritelerin devlete destek ve güven mesajlarının sunulması uslamlamaya örnektir. Yetkili ve uzman kişilerin görüşlerinden faydalanılarak kavrama yönelik destek pekiştirilmektedir. Haberin iç sayfada yer alan bölümünde başlık olarak ekonomi bakanının "Dik duracağız, ekonomik savaşı kaybetmeyeceğiz" sözü kullanılmıştır. Sözü söyleyen gazete olmasa da genel olarak başığa taşınan ifadenin verdiği mesajın önemsendiği ve bu yönde bir söylem oluşturduğu görülmektedir. "Ekonomik savaş" tanımlamasıyla mağduriyet vurgulanmakta ve ülke kurban olarak gösterilmektedir. Bu şekilde bir anlatı, okuyucuların mağdura empati duymasını ve duruma karşı destek vermesini sağlarken, diğer taraftan hükümeti ekonomi politikaları ile ilgili olarak hesap vermekten ve sorumluluklarından muaf tutmaktadır.

\section{Birgün Gazetesi, "Saray'da lüks ve israf halkta borç yükü var”, 25 Eylül 2018}

“... AKP'nin "Ekonomik kriz yok” söylemini eleştiren CHP Genel Başkan Yardımcısı Oğuz Kaan Salıcı, "Türkiye'de ekonomi, saray ekonomisi ve halkın ekonomisi olmak üzere ikiye ayrılıyor. Saray ekonomisinde şatafat var, savurganlık, israf var. Ama halkın ekonomisine baktığımız zaman orada kriz var, yoksulluk var, borç yükü var, işsizlik var" ifadelerini kullandı... çocuğuna pantolon alamadığı için intihar eden babanın, Urfa'da kendini yakan gencin olduğunu ifade etti..."

Haberin başlığında "saray" ve "halk" ikili karşıtığı çerçevesinde iktidar ile halk arasında ekonomik koşulları açısından bir ayrışma olduğuna işaret edilmekte, halkın yoksulluğu ve yaşam koşullarının zorluğu vurgulanmaktadır. Başııta kullanılan cümle CHP'li bir siyasetçiye ait olsa da o cümlenin başlığa taşınması o noktaya dikkat çekilmesi anlamına gelmekte; direkt alıntı yapılması da aynı görüşün paylaşıldığını göstermektedir. Haberin durum tanımlayıcısı olan bir aktörün sözünün doğrudan aktarılması yoluyla "halkın borç yükü", "krizden dolayı intihar eden baba", "kendini yakan genç" ifadelerle mağdur olanın halk olduğu dramatik bir retorikle verilmiştir.

\section{Hürriyet Gazetesi, “ İkinci Çeyrekte 5.2 Büyüdük”, 11 Eylül 2018}

"Türkiye ekonomisi, 2018'in ikinci çeyreğinde beklentilere uygun şekilde yüzde 5. 2 oranında büyüdü.

"DENGELENME SÜRECI BAŞLADI": Hazine ve Maliye Bakanı Albayrak, "Büyüme, tüketim ve yatırımdaki ılımlı yavaşlamaya rağmen iç talep kaynaklı olmaya devam etmiştir. Bu durum, ekonomi politikalarımızdaki temel hedeflerimizin başında gelen ekonominin dengelenme sürecinin başladığını göstermektedir" dedi ( Manşetten verilen bölüm). 
...KARARLI MÜCADELE “...Son dönemde finansal koşullarda ortaya çıkan sıkılaşma ve piyasalarımızda yaşanan dalgalanma temelde enflasyon ve cari açık alanlarındaki kırılganlıklarımızla daha kararlı mücadele etmeyi ve makroekonomik dengelenme politika setini oluşturmayı gerektirmektedir..."

Hürriyet Gazetesindeki haberin başlığında Hazine ve Maliye Bakanının sözü olumlama yapılarak verilmiştir. Haberin spotunda geçen "beklentilere uygun şekilde" ifadesiyle ekonomide durumun kontrol altında olduğu yönünde bir vurgu yapılmıştır. Haberdeki sayısal veriler haberin güvenilirlik düzeyini artırmak ve bir kanıt sunmak amacıyla verilmişsir. Haber içeriğinde genel olarak Bakanın sözleri aktarılmıştır. Burada da gazetenin büyük puntolarla yazdığı bir başka deyişle öne çıkarmak istediği başlıklar göze çarpmaktadır. "Kararlı mücadele" ifadesinin ara başlık olarak sunulması da bir anlamda hükümetin durum tanımlarını yeniden üretmiştir.

Sabah, "Ekonomide 15 Temmuz Ruhu", 14 Ağustos 2018

"Ekonomik saldırılara kalkışan ihanet odaklarına en güzel yanıtı, milli birlik ruhuyla kenetlenen vatandaşlar verdi. Başkan Erdoğan'ın çağrısıyla tüm yurtta dolar bozdurma yarışı başladı. İstanbul'da TÜMKIAD üyeleri 3 milyon dolar, Kocaeli'nde iki gurbetçi 85 bin euro bozdurdu. Bolu'da da pazarcılar dolar bozdurandan para almadı...( Manşetten verilen bölüm)

“Türkiye'ye yönelik ekonomik savaşa, yurt genelinde 15 Temmuz benzeri milli birlik ve beraberlik ruhuyla cevap verildi. Anadolu'nun dört bir yanından Başkan Tayyip Erdoğan'ın çağrısını karşııısız bırakmayan vatandaşlar, 15 Temmuz'da olduğu gibi bu oyunu da bozacaklarını söylediler...Tüm Kalkınma İşadamları ve Girişimciler Derneği (TÜMKIAD) Başkanı Nihat Tanrıkulu ile 300 dernek üyesi, Istiklal Caddesi'nde bir döviz bürosuna giderek, 3 milyon doları bozdurup TL'ye çevirdi. Tanrıkulu, "Bize dolar değil vatan lazım" mesajı verdi..."

Sabah Gazetesinin haber başlığında kullanılan "15 Temmuz Ruhu" ifadesiyle 15 Temmuz'da yaşanan darbe girişimi ile ekonomik kriz özdeşleştirilerek ekonomide yaşanan olumsuz tablonun ekonomi temelli nedenleri ve çözüm yolları tartışılmak yerine, bir saldırı altında olma anlatısı üzerinden mağdur "biz", düşman "onlar" ikili karşıtlığı kurulmuştur. "Darbeye karşı mücadele" siyasetin egemen ideolojisi olduğundan ekonomi ile ilgili sorunlar da bu perspektifle değerlendirilmiştir. Bu tür anlatılar, daha çok bir düşman etrafında birleşme duygusu yarattığından bir anlamda toplumsal tepkiyi de önleyici bir rol oynamaktadır. "15 Temmuz'da olduğu gibi oyunu bozacaklar" ifadesiyle de oluşturulmak istenen birleştirici tutum pekiştirilmektedir. "Saldırı" sözcüğü bir "mağdur"u da beraberinde getirmektedir. Haber içeriğinde verilen birlik ve destek mesajları, "biz"i tehdit eden "onlar" vurgusunu içermektedir.

\section{Sözcü, "Tasarruf Diyorlar Ama Meclis Halı Değiştiriyor”, 15 Eylül 2018}

"BU NE PERHIZ, BU NE LAHANA TURŞUSU Tasarruf diyorlar ama Meclis halı değiştiriyor TBMM'deki kırmızı halılar sökülüp yerine turkuaz renklisi döşeniyor Bu ekonomik kriz ortamında halkın milyonlarca lirası sokağa atılıyor... YANLıŞ ekonomik politikalar yüzünden Türkiye krize sürüklenirken iktidar halka ve kamuya tasarruf çağrısı yaptı. Ancak bunu_, Meclis duymadı. Millet krizde 
inim inim inlerken halı değiştirme kararı aldı... ISRAFIN DANISKASI' Ege Üniversitesi Tıp Fakültesi Hastanesi'nde kağıt olmaması nedeniyle hastaların raporlarının basılmadığını belirten Sertel, 1 Ekim'de açılacak olan Türkiye Büyük Millet Meclisi'nin halılarının değiştirilmesine tepki gösterdi..."

Sözcü Gazetesi, “ tasarruf diyorlar ama meclis halı değiştiriyor” ifadesi ile hükümet karşıtı ve merkez-sol perspektiften eleştirel bir yaklaşım getirmiştir. Haberde sürmanşette verilen "bu ne perhiz, bu ne lahana turşusu" ifadesinin büyük puntolu bir şekilde verilmesiyle okuyucunun bu noktalara dikkatinin çekilmesi amaçlanmış, iktidarın tasarruftan ve birlikten bahsederken uygulamada bu durumu yansıtmadığı, iktidar ile halkın önceliklerinin aynı olmadığı gösterilmek istenmiştir. Krizin mağdur olanının halk olduğu, durumdan iktidarın etkilenmediği vurgulanmıştır. Haberde geçen "YANLIŞ ekonomik politikalar" ifadesinde "yanlış" kelimesine dikkat çekilmesinin amacı, yaşanan krizin nedeninin iktidarın ekonomi politikalarından kaynaklandığı belirtilmiştir. Haberdeki sözcük seçimleri gazetenin konuya yönelik eleştirel tutumunu yansıtmıştır.

Yeni Şafak, "Borsa 4 Ayın En Yükseğinde”, 28 Eylül 2018

"Ekonomideki spekülatif kara bulutlar dağıldı. Dün yüzde 1, 16 değer kazanarak 100. 298 puanı gören Borsa, son 4 ayın en yüksek kapanışı yaptı... Borsa yükseldi DOLAR ÇAKILDI Türkiye'ye açılan ekonomik savaşın borsa ve dolar kuruna yönelik etkileri dağılmaya başladı. Yapılan bütün manipülasyonlara rağmen dün BIST 100 endeksi 4 ay aradan sonra 100 binin üzerini, dolar ise 6 liranın altını gördü. Ekonomik kriz algısı oluşturmak için Türkiye'ye yönelik dışarıdan yapılan manipülasyonların etkisi dağılmaya başladı... Türkiye'nin ekonomik dalgalanma karşısında siyasi olarak sağlam durmasıyla Borsa İstanbul endeksi ve döviz kurları gerçek değerine doğru ilerlemeye başladı. BIST 100 endeksi 100. 298, 73 puanla yaklaşık 4 ayın en yüksek kapanışını gerçekleştirdi. Dolar ise son günlerdeki düşüş eğilimini sürdürerek dün 6 lira seviyesinin altına inerek ve 5. 98'den işlem gördü..."

Yeni Şafak Gazetesinin "Borsa 4 Ayın En Yükseğinde” başlıklı haberi ile okuyucuya olumlu bir tablo çizilmiştir. Okuyucunun zihninde yaratılan olumlu çağrışımlar, "kara bulutlar dağıldı", "dolar çakıldı" şeklindeki ifadelerle pekiştirilmiştir. Haber içeriğinde ekonomik krizin aslında olmadığı bunun "manipülasyon" olduğu vurgusu yapılarak iktidar söylemi yeniden üretilmiştir. Haber içerisinde kullanılan "ekonomik savaş" ve "dolar çakıldı" ifadeleri birlikte değerlendirildiğinde bir ikili karşıtlık kurulduğu görülmektedir. Bu kapsamda, ülke ekonomisinin bir savaş verdiği belirtilerek bir anlamda hükümetin ekonomik duruma yönelik sorumluluğu arka plana itilmiş ve krizin sorumluluğu bir savaş metaforuyla bize karşı olan "onlar" a yüklenmiştir.. "Dolar çakıldı" ifadesinin büyük puntolu ve abartılı bir şekilde sunulması da okuyucunun dikkatini ve algısını bu yöne çekmeye yönelik bir stratejidir. Nitekim, haberin devamına bakıldığında verilen sayısal değerlerle "çakıldı" şeklinde sunulan dolar değerinin abartıldığı kadar düşüş göstermediği görülmektedir. Haberde sayısal verilere yer verilmesinin bir nedeni de haberin inandırıcılığını ve güvenilirliğini artırmaktır. Burada sayısal değerler verilirken de daha çok olumlu artış gösteren durumların öne çıkarıldığını söylemek mümkündür. 
Cumhuriyet, "YEP Yurttaşa Umut Vermedi”, 24 Eylül 2018,

"Yeni Ekonomi Programı (YEP)'nda işsizlik oranının çift hanede seyredecek olması, yurttaşın kaygılarını iyice artırdı... BBC'nin YEP verileriyle ilgili Ankara Ulus'ta konuştuğu bazı yurttaşlar, ekonominin düzeleceğine dair ümit beslese de, birçok kişi yakın gelecekte ekonominin düzeleceğine dair kuşku taşıyor... Çember daralıyor... Gelecek 3 yıl için yapılan tahminler, işsizlik oranının tek hanelere düşmeyeceğini gösteriyor...Milli Piyango bileti satışı yaparak geçinen ibrahim Servet Seçkin, "Çember bizim gibi dar gelirli insanlar için giderek daralacak... Bugün 5 kilo yağın 35-40 TL, domatesin kilosunun 5-6 TL olduğu yerde kim krizden nasıl etkileniyorsa ben de o kadar etkileniyorum... Dokuz Eylül Üniversitesi öğretim Üyesi Prof. Dr. Yaşar Uysal, 2019'un birinci ve ikinci çeyreğinde Türkiye'nin büyüme rakamlarında eksiye düşebileceği öngörüsünde bulundu... YEP'de 2021 yılı enflasyon hedefinin yüzde 6 açıklanmasına karşın Türkiye'nin kısa süre önce 10 yıllığına yüzde 20. 7 faizle borçlandığını hatırlatan Uysal, "Ne yazık ki örtülü kur hedefi, cari açık ve işsizlik başta olmak üzere YEPteki bazı hedeflerin tutmadığını görebiliriz" dedi..."

Cumhuriyet Gazetesinin "YEP yurttaşa umut vermedi" başlığıyla Hazine ve Maliye Bakanı tarafından açıklanan ekonomik programına yönelik olumsuz bir dil kullanılmıştır. Haber başlığını desteklemek amacıyla röportaj yapılan halkın görüşlerine yer verilerek egemen sınıfların dışında kalan toplum kesimleri de durum tanımlayıcısı olarak habere dahil edilmiştir. Haberde halkın söylemi olan "5 kilo yağın fiyatı" gibi tüketim maddelerine yönelik zamların ön plana çıkarıldığı ifadelere yer verilerek mevcut ekonomik duruma yönelik negatif bir tablo sunulmuştur. Haberde ekonomik konularda uzman kişinin görüşlerine yer verilmesiyle uslamlama yapılmıştır.

\section{Star, “\#KAZANACAĞIZ”, 12 Ağustos 2018}

“Ünlülerden siyasetçilere 7'den 70'e herkes ekonomik savaşa karsı el ele verdi... Türkücü Ibrahim Tatıses doların yükselişi ve Türkiye gündemi ile ilgili beğeni toplayan bir paylaşım yaptı. Tatııses "Bayrağımızı göğsüne koyan, hiç bir zaman üstüne basmayan, diğerleri boş boş bakarken önce bayrağını düşünen bir adam var. Ne aç kalırız ne de açıkta kalınz... BAYRAĞINI DÜŞÜNEN BiR LIDERIMIZ VAR OYUNU BIRLIKTE BOZACAĞIZ... Şarkıcı Serkan Kaya..."Dış güçlerin oyununu hep birlikte bozacağız, şüpheniz olmasın. Hem de şarkılar, türküler söyleye söyleye"... "OYUNU BIRLIKTE BOZACAĞIZ"...

Star Gazetesinin "\#Kazanacağız" başlıklı haberi de yine "savaş kazanma" retoriği üzerine kurulu bir karşıtlık üretme örneği oluşturmaktadır. Haberde genel olarak ünlü kişilerin destek temalı ifadelerine yer verilmesiyle ekonomik krizde iktidara destek mesajı verilmiştir. Haber içeriğindeki "ekonomik savaş" ifadesi yaşanan krizin nedeninin dış güçler olduğu vurgulanmıştır. Haberin devamında ülkenin yöneticileri ile ilgili verilen "BAYRAĞINI DÜŞÜNEN LIDER" şeklindeki büyük puntolu ifadeler ile savaş miti milli değerlerle birleştirilmiştir. "OYUNU BIRLIKTE BOZACAĞIZ" mesajıyla da savaş ve mücadele söylemi üretilmiş ve hükümet milliyetçi ideoloji üzerinden desteklenmiştir. 


\section{Sonuc}

Bu çalışma, 2018 döviz kuru krizi örnek olayı çerçevesinde iki temel araştırma sorusuna cevap aramaya çalışmış; ilk olarak, "medyanın ekonomik krizle ilgili söylemlerinin kapitalizmi nasıl yeniden ürettiği” sorusunu irdelemiştir. Buna göre, özellikle muhafazakâr ve liberal gazetelerin konuyu neoliberal bir perspektiften ele aldıkları ve temelde kapitalizmin doğasından kaynaklanan kriz üretme potansiyeline ve çelişkilerine değinmedikleri görülmüştür. Ekonomi temelinde rasyonel bir tartışma sol ideolojik çizgideki gazetelerde daha yoğun bir şekilde yürütülse de buradaki tartışmalar da hükümet eleştirisini merkezine almış, ancak kapitalizmin yarattığı yapısal sorunları tartışmamıştır. Özellikle, Cumhuriyet ve Sözcü gazeteleri yine kapitalizmin sınırları içinde kalarak konuyu iktidar partisinin yanlış ekonomi politikaları ve bunun zam ve enflasyon olarak gündelik hayata yansımaları temelinde ele almıştır. Ancak, Birgün gazetesi diğerlerinden farklı olarak, ekonomik kriz olgusunu tanımlarken ve dinamiklerini ortaya koyarken ekonomik eşitsizlikleri ve sınıfsal çelişkileri görmüş, daha kavramsal temelde ve rasyonel bir haber çerçevesi çizmiş, özellikle ezilen toplumsal sınıfların maruz kaldığı ekonomik eşitsizliklere ve işçilerin sorunlarına değinmiştir. Diğer taraftan liberal-sağ çizgideki gazeteler haber üretimini kapitalizmin tezlerine ve mantığına göre oluşturmuş, yaşanan ekonomik krizle ilgili değerlendirmeler nedenlerinden çok sonuçları üzerinden değerlendirilmiştir. Muhafazakâr ve liberal medya, "borsa yükseldi", "Dolar düştü", "enflasyonla mücadele" gibi olumlu tanımlamaları ile kapitalist söylemi yeniden üretmiştir.

Çalışmanın bir diğer sorusu ise, "medyanın ekonomik sorunları ve döviz kuru krizini nasıl tanımladığı ve haber içeriklerinin iktidar söylemini yeniden üretip üretmediği”dir. $\mathrm{Bu}$ araştırma sorusu kapsamında değerlendirme yapıldığında, keskin bir ideolojik kutuplaşmanın ön plana çıktığını ve muhafazakâr ve liberal medyanın durum tanımlarının hükümetinkiyle paralellik gösterdiğini söylemek mümkündür. Muhafazakâr ve liberal medya, haber dilinde iktidarın söylemini yeniden üretirken, sol medya ise tamamen karşı-hegemonik bir söylem geliştirmiştir. Bu örnek olay incelemesi, siyaset alanındaki kutuplaşmanın ve iktidar mücadelesinin medya alanını da biçimlendirdiğini ve partizan bir medya örüntüsünün ortaya çıktığını göstermektedir.

Medya rasyonel gerekçelerden çok, hükümet taraftarlığı veya karşıtığı üzerinden haber dilini kurmaktadır. Ayrıca, sermaye medyası ve siyasî iktidar arasındaki güçlü ittifak; haber medyasında tek yönlü ve türdeş bir içeriğin oluşturulması, egemen ideolojinin medya aracılığıyla meşrulaştırılması ve yeniden üretilmesi sonucunu doğurmaktadır. Muhafazakâr ve liberal medya, yaşanan ekonomik sorunları "ekonomik savaş", "ekonomik saldırı", "kur saldırısı" şeklinde adlandırarak dış faktörlerin etkisini daha görünür kılmış ve bunun dışarıdan bir etkiyle ortaya çıktığını ileri sürmüştür. Ancak, muhalif ve sol medya ise sorunun kaynağını ve çözümünü ekonomi politikalarında ve ekonomi disiplininin dinamikleri içinde tartışmış ve hükümete yönelik bir eleştiri getirmiş ve kriz durumunu "ekonomik darboğaz" ve "ekonomik çöküş" gibi olumsuz sözcük seçimleriyle tasvir etmiştir. Ancak, her iki taraftaki haber perspektifi de konuyu ekonomi diliyle tartışmaktan çok siyasetin diliyle tartışmış ve kutuplaşma haberin diline yansımıştır. 
Ekonomik krizin sunumuna dair yapılan niceliksel inceleme de dildeki ideolojik mücadeleyi göstermiştir. İdeolojik olarak "sol eğilimli" gazeteler diğerlerine oranla konuyu daha çok haberleştirmiş ve gündemde tutmaya çalışmıştır. Yine bu gazeteler kullandıkları "çöküş", "darboğaz" "çıkmaz" türündeki olumsuz anlam taşıyan sözcükleri kullanarak okuyucuya olumsuz bir çerçeve sunmuştur. Bu gazetelerin haber ve köşe yazılarının genelinde ekonomik krizin varlığı ve ciddi boyutlara ulaştığı, halk ile devletin aynı tarafta olmadığı, mağdur olanın halk olduğu sıklıkla vurgulanmıştır. Sol ve iktidara muhalif çizgideki gazetelerin ekonomik krize yönelik haberlerinin birçoğunda ekonomik krize yönelik uzman görüşlerinden ve sayısal verilerden de yararlandığı, böylece gazetelerin otoriteye başvurma ve kanıt sunma aracılığıyla haberin güvenilirliğini yükseltmeyi amaçladığı görülmüştür.

İdeolojik olarak muhafazakâr ve liberal gazetelerin ekonomik krize yaklaşımı daha "sol eğilimli" gazetelere oranla daha temkinli olmuştur. Bu gazeteler, ekonomik kriz ifadesi yerine sıklıkla "ekonomik saldırı", "ekonomik savaş" ve "kur saldırısı" ifadelerini kullanmışlar ve hükümet yetkililerinin açıklamalarına daha fazla yer vermişlerdir. Ekonomik krize yönelik yapılan haberlerin çoğunda ekonomik saldırılara karşı halkın birlik içinde olması gerektiği, sorunun milli bir mesele olduğu ve dış güçlerin ülkemizi zor duruma sokmak istediği yönünde bir anlatı kurulmuştur. "Enflasyonla mücadele" başıı̆ını ve temasını sıkça kullanan bu gazeteler, genel olarak ünlü kişilerin ve iş insanlarının destek mesajlarına da yer vererek birlik ve beraberlik duygusunu güçlendirmeyi amaçlamışlar ve ekonomik sorunlara milliyetçi değerler üzerinden ve ekonominin kavramsal çerçevesinin dışından bir açıklama getirmişlerdir.

Van Dijk (1995: 25-26)'ın da belirttiği gibi, kitle iletişim araçları kapitalist üretim tarzıyla derinlemesine bütünleşen şirketlerdir ve serbest piyasa ideolojisi her şeyden önemlidir. Dolayısıyla, haber medyası buna nadiren meydan okumaktadır. İş ve ekonomi haberleri de çoğunlukla iş yerindekilere değil, iş dünyasının elitlerine odaklanmaktadır Kriz durumlarında ise, yönetimin perspektifi durum tanımlarında, röportajlarda, alıntılarda, konu başlıklarında ve haber kapsamında daha yaygın hale gelmektedir. Bu çalışma, özellikle kriz zamanlarında, anaakım medyanın siyasal iktidarın söylemini nasıl yeniden ürettiğini bir kez daha ortaya koymuştur.

\section{Kaynakça}

Akçay, Ü. (2018). Beş soruda 2018-2019 ekonomik krizi. https://www.gazeteduvar.com. tr/yazarlar/2018/12/13/bes-soruda-2018-2019-ekonomik-krizil, 13.12.2018. Erişim tarihi: 16.02.2019.

Barker, C. and Galasiński, D. (2001). Cultural studies and discourse analysis: A dialogue on language and identity. London: Sage.

Bergström, G. and Boréus, K. (2017). Analyzing Text and Discourse in the Social Sciences. Analyzing Text and Discourse: Eight Approaches For The Social Sciences, İçinde: Kristina Boréus and Göran Bergström (eds.), London: Sage.

Berry, M. (2019). The Media, the Public and the Great Financial Crisis. Palgrave Macmillan. 
Croteau, D. \& Hoynes, W. (2014). Media/Society: Industries, Images, and Audiences, Thousand Oaks, California: Sage.

Fairclough, N. (2003). Söylemin Diyalektiği. İçinde Söylem ve İdeoloji, Barış Çoban ve Zeynep Özarslan (haz.), ss. 173-184, İstanbul: Su Yayınları.

Fairclough, N. (2003a). Analysing Discourse: Textual analysis for social research. London: Routledge.

Hall, S. (2013). Introduction, In: Representation: Cultural Representations and Signifying Practices. Hall, S., Evans, J. and Nixon, S (eds.), London: Sage.

İnal, A. (1996). Haberi Okumak, Temuçin Yayınları, İstanbul.

MiSAM (Mülkiye İktisadi ve Sosyal Araştırmalar Merkezi). 2018 Yılı Döviz Kuru Krizi'ne İlişkin Görüş. http://mulkiye.org.tr/2018-yili-doviz-kuru-krizine-iliskin-gorus/, Erişim tarihi: 16.02.2019.

Özer, Ö. (2018). Gökyüzüne Çığlık: Öncülerden Eleştirel Söylem Yaklaşımları ve Örnek Çözümlemeler. Konya: Literatürk.

Phelan, S. (2014). Neoliberalism, Media and the Political, New York, N.Y. Palgrave Macmillan.

Scharp, K.M. and Thomas, L. J. (2017). Discourse Analysis. The International Encyclopedia of Communication Research Methods, Volume I, In Jörg Matthes (ed.), Hoboken: Wiley Blackwell, ss. $473-481$.

Schiffrin, A. (2015). The Press and the Financial Crisis: A Review of the Literature. Sociology Compass 9/8 (2015): 639-653, 10.1111/soc4.12288

Şen, F. ve Avşar, Z. (2012). «Türkiye'de Neoliberal Politikaların Haber Medyasına Yansımaları: Anaakım Medyanın Ekonomi Haberleri Üzerine Bir İnceleme», Gazi Üniversitesi Illetişim Fakültesi İletişim Kuram ve Araştırma Dergisi, Sayı: 35, ss.42-60.

Temple, L. (2015). Neoliberalism, austerity and the UK media, SPERI British Political Economy Brief No. 18, Sheffield.

Van Dijk, T. A. (1986). "News Schemata", İçinde: S Charles Raymond Cooper ve Sidney Greenbaum, (Ed.), Studying Writing. Linguistic approaches, Beverly Hills, CA: Sage, ss. 155-186.

Van Dijk, T.A., (1988). News As Discourse, Hillsdale, New Jersey: Lawrence Erlbaum Associates Publishers.

Van Dijk, T.A. (1995). Power and the News Media, Içinde: David Paletz (ed.), Political communication in action : states, institutions, movements, audiences, ss.9-36, NJ : Hampton Press.

Van Dijk, T. A. (1999). "Söylemin Yapıları ve İktidarın Yapıları", Medya, iktidar, İdeoloji, Mehmet Küçük (der.) içinde, Ark Yayınları, Ankara.

Van Dijk, T. A. (2009). News, Discourse, and Ideology. The Handbook Of Journalism Studies. İçinde Karin Wahl-Jorgensen ve Thomas Hanitzsch (ed.). s. 191-204. New York: Routledge.

Van Dijk, T. A. (2011). Introduction: The Study of Discourse. Discourse Studies: A Multidisciplinary Introduction. In: Teun A. van Dijk (Ed.). London: Sage. 
Van Dijk, T.A. (2016). Critical Discourse Studies: A Sociocognitive Approach. Methods of Critical Discourse Studies. In: Ruth Wodak and Michael Meyer (eds.). London: Sage.

Wodak, R. \& Meyer, M. (2016). Critical Discourse Studies: History, Agenda, Theory, and Methodology, Methods of Critical Discourse Studies. In: Ruth Wodak \& Michael Meyer (eds.). London: Sage.

Wooffitt, R. (2005). Conversation Analysis and Discourse Analysis: A Comparative and Critical Introduction. London: Sage. 